\title{
Research on Wear of Liners in Diesel Engines During Start-ups
}

\author{
Paweł Droździel $^{1}$, Piotr Ignaciuk ${ }^{1}$, Paweł Kordos ${ }^{1}$ \\ ${ }^{1}$ Faculty of Mechanical Engineering, Lublin University of Technology, Nadbystrzycka 36, 20-618 Lublin, Poland
}

\begin{abstract}
This paper presents the methodology and results of tests of the start-up wear of the cylinder liner in vehicle diesel engines. The conducted tests were aimed at determining the starting wear of the cylinder liner, as well as the influence of the starting temperature and other factors on the observed wear value.
\end{abstract}

Keywords diesel engine, cylinder testing, starting wear testing

JEL L62, L90, C15

\section{Introduction}

The start-up of a vehicle internal combustion engine is a transitional process accompanied by the occurrence of many negative tribological processes. At the beginning of the startup, due to insufficient amount of engine oil (inertia of the engine lubrication system) and too low relative velocity of the moving surfaces of its tribological pairs, the occurrence of the so-called boundary friction is noted $[5,6,10]$.

As the engine oil flows to the engine tribological nodes, the boundary friction turns into mixed friction. Only when a sufficient relative velocity and amount of lubricating oil are achieved between the moving surfaces of kinematic pairs (usually occurring after the engine start-up), favourable conditions for the occurrence of liquid friction appear [7,10,11]. The described transition from boundary friction (in extreme cases from dry friction) to mixed friction with a low percentage of liquid friction causes that adhesive and abrasive wear can be observed in the tribological nodes of the internal combustion engine during start-up, in addition to corrosive wear in the PRC system $[6,8]$.

As a result, the start-up wear is characterized by a higher wear rate than that occurring during the normal operation of the internal combustion engine The start-up wear of the cylinder liner bearing surface during a single start of an internal combustion engine constitutes from $8 \%$ to $75 \%$ of its total operational wear. The values of the equivalent start-up wear range from a few to several hundred or even several thousand kilometres of vehicle mileage or several (up to 10) hours of operation on an engine test bench $[6,11]$.

\section{Research objects and the methodology of research}

The research was conducted on 359M and 4CT90 diesel engines. The basic technical parameters of these engines are presented in Table 1.

Table 1. Selected technical parameters of the 359M and 4CT90 engines

\begin{tabular}{|l|c|c|}
\hline \multirow{2}{*}{ Specification } & \multicolumn{2}{|c|}{ Engine parameter value } \\
\cline { 2 - 3 } & $359 \mathrm{M}$ & $4 \mathrm{CT} 90$ \\
\hline Number of cylinders [pcs.] & 6 & 4 \\
\hline Cylinder diameter [mm] & 110 & 90 \\
\hline Stroke [mm] & 120 & 95 \\
\hline Displacement [dm ${ }^{3}$ ] & 6.842 & 2.417 \\
\hline Compression ratio & 17 & 20.6 \\
\hline Rated power [kW] & 110 & 66 \\
\hline Rotational speed of rated power [rpm] & 2800 & 4100 \\
\hline Maximum torque [Nm] & 440 & 195 \\
\hline Rotational speed at the max torque [rpm] & $1800-2100$ & 2500 \\
\hline Idle speed [rpm] & $500-600$ & $800 \pm 20$ \\
\hline Maximum rotational speed [rpm] & 3100 & 4100 \\
\hline Compression pressure [MPa] & 2.4 & 3.0 \\
\hline Oil pressure in the lubrication system [MPa] & $0.2-0$. & $0.38-0$. \\
\hline
\end{tabular}

The PRC system of the 4CT90 engine uses a piston with two sealing rings and one wiper ring. In the PRC system of the $359 \mathrm{M}$ engine, the piston is sealed in the cylinder liner by three O-rings and includes one wiper ring.

The wear assessment of cylinder liner bearing surfaces during the start-up of the tested engines was carried out on a special engine testbed at the Department of Internal Combustion Engines, Lublin University of Technology. Electronic measurement and control systems used on the stand allowed for continuous control of the temperature of the coolant and engine oil. A heater and a water cooler in the engine oil pan, as well as a heater in the engine coolant heat exchanger and 
a water pump operating when the engine is stopped, were installed to stabilize the above-mentioned temperatures. Fluctuations in coolant and lubricating oil temperatures during the series of start-ups did not exceed $\pm 2.5^{\circ} \mathrm{C}$.

For the tested diesel engines, a series of start-ups was performed with the parameters shown in Table 2. After starting, the engine idled for several dozen seconds. After the engine was stopped, it was brought back to the assumed start-up temperature.

Table 2. Parameters of the various start-up series of the $359 \mathrm{M}$ and 4CT90 engines

\begin{tabular}{|c|c|c|c|c|c|}
\hline $\begin{array}{c}\text { Series } \\
\begin{array}{c}359 \\
\text { engine }\end{array}\end{array}$ & $\begin{array}{c}\text { Number } \\
\text { of } \\
\text { engine } \\
\text { start-ups } \\
\text { and lu- } \\
\text { bricating } \\
\text { oil tem- } \\
\text { perature } \\
{[\mathrm{K}]}\end{array}$ & $\begin{array}{c}\text { Series } \\
\text { 4CT90 } \\
\text { engine }\end{array}$ & $\begin{array}{c}\text { Number } \\
\text { of } \\
\text { engine } \\
\text { start-ups }\end{array}$ & $\begin{array}{c}\text { Water and } \\
\text { lubricat- } \\
\text { ing oil } \\
\text { tempera- } \\
\text { ture } \\
{[\mathrm{K}]}\end{array}$ \\
\hline $\begin{array}{c}\text { Series } \\
\text { no. } 1\end{array}$ & 500 & $\begin{array}{c}283 \\
\left(10^{\circ} \mathrm{C}\right)\end{array}$ & $\begin{array}{c}\text { Series } \\
\text { no. } 1\end{array}$ & 1000 & $\begin{array}{c}291 \\
\left(18^{\circ} \mathrm{C}\right)\end{array}$ \\
\hline $\begin{array}{c}\text { Series } \\
\text { no. } 2\end{array}$ & 700 & $\begin{array}{c}293 \\
\left(20^{\circ} \mathrm{C}\right)\end{array}$ & $\begin{array}{c}\text { Series } \\
\text { no. } 2\end{array}$ & 1000 & $\begin{array}{c}308 \\
\left(35^{\circ} \mathrm{C}\right)\end{array}$ \\
\hline $\begin{array}{c}\text { Series } \\
\text { no. } 3\end{array}$ & 1000 & $\begin{array}{c}333 \\
\left(60^{\circ} \mathrm{C}\right)\end{array}$ & $\begin{array}{c}\text { Series } \\
\text { no. } 3\end{array}$ & 1000 & $\begin{array}{c}328 \\
\left(55^{\circ} \mathrm{C}\right)\end{array}$ \\
\hline & & $\begin{array}{c}\text { Series } \\
\text { no. } 4\end{array}$ & 1000 & $\begin{array}{c}248 \\
\left(75^{\circ} \mathrm{C}\right)\end{array}$ \\
\hline
\end{tabular}

\section{Methodology of testing the wear of cylinder liners}

In the conducted tests, the increase in their internal diameter was assumed as a measure of the wear of cylinder liners in the 359M and 4CT90 engines. In order to determine this increase, the surface of individual cylinder liners was cut with a diamond blade, creating the so-called "artificial bases". A special UPOI6 device was used for this purpose. The applied wear assessment method is characterized by an accuracy of $1 \mu \mathrm{m}$.

In order to avoid complete disassembly of the engines, the "artificial bases" were cut only after removing the head. This was done in accordance with the Industry Standard BN79/1374-04, perpendicular to the direction of friction in measurement planes (levels) at different heights of the cylinder liner measured from the block surface and for four directions - parallel (A-A) to the crankshaft axis, perpendicular (B-B) to this axis and at an angle of $45^{\circ} \mathrm{C}$ to the crankshaft axis (C-C, D-D), as shown in Figure 1.

The first three measurement planes for the 4CT90 engine and the four measurement levels for the $359 \mathrm{M}$ engine correspond to the centers of their piston ring positions at TDC. The greater number of measurement levels of the 4CT90 engine resulted from better technological possibilities of cutting the "artificial base". The "artificial bases" cut in each measurement plane were marked sequentially from 1 to 8 clockwise, starting from the base on the A-A direction closest to the front of the engine.
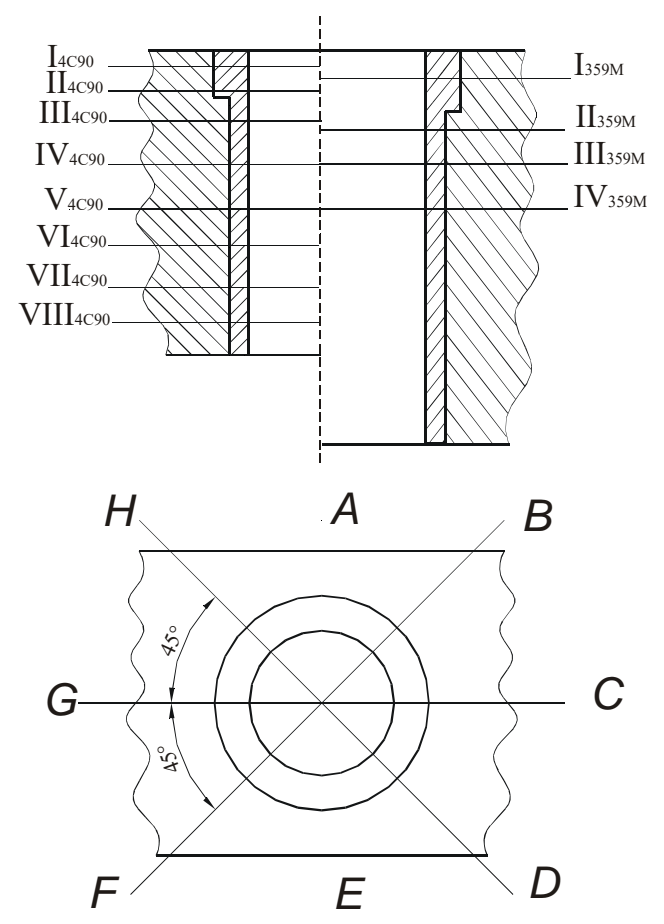

Figure 1. Scheme of cutting artificial bases on the surface of cylinder liners of the tested engines; height (level) of notching the bases along the 4CT90: $-23 \mathrm{~mm}, \mathrm{III}_{4 \mathrm{CT} 90}-30 \mathrm{~mm}, \mathrm{IV}_{4 \mathrm{CT} 90}-40 \mathrm{~mm}, \mathrm{~V}_{4 \mathrm{CT} 90}$ $-50 \mathrm{~mm}, \mathrm{VI}_{4 \mathrm{CT} 90}-60 \mathrm{~mm}, \mathrm{VII}_{4 \mathrm{CT} 90}-70 \mathrm{~mm}$ and the $359 \mathrm{M}$ engine: $\mathrm{I}_{359 \mathrm{M}}-23 \mathrm{~mm}, \mathrm{II}_{359 \mathrm{M}}-36.5 \mathrm{~mm}, \mathrm{III}_{359}-55.5 \mathrm{~mm}$.

The first three measurement planes for the 4CT90 engine and the four measurement levels for the $359 \mathrm{M}$ engine correspond to the centers of their piston ring positions at TDC. The greater number of measurement levels of the 4CT90 engine resulted from better technological possibilities of cutting the "artificial base". The "artificial bases" cut in each measurement plane were marked sequentially from 1 to 8 clockwise, starting from the base on the A-A direction closest to the front of the engine.

After each series of start-ups, the engine head was removed and the changes in the length of the "artificial base" were read, which made it possible to assess the wear of the cylinder liner surface (increase in its internal diameter). The value of the single radial wear of the liner surface is calculated from the following formula, see Figure 2:

$$
Z_{r i}=\frac{1}{8} \cdot\left(\frac{1}{r}-\frac{1}{R}\right) \cdot\left(l_{p}^{2}-l_{k}^{2}\right),
$$

where:

$\mathbf{z}_{\boldsymbol{r}}$ - value of the $\boldsymbol{i}$-th radial wear of the cylinder liner $[\mu \mathrm{m}]$,

$\boldsymbol{r}$ - knife radius $9.4[\mathrm{~mm}]$,

$\boldsymbol{R}$ - radius of curvature of the tested surface 45 or 55 [mm],

$\boldsymbol{I}_{\boldsymbol{p}}$ - initial cut length $[\mu \mathrm{m}]$,

$\boldsymbol{I}_{\boldsymbol{k}}-$ end length of the cut, $[\mu \mathrm{m}]$. 
The value of wear (increase) of the inner diameter of the cylinder liner is:

$$
d_{i}=z_{r x j}+z_{r x k},
$$

where:

$\boldsymbol{d}_{\boldsymbol{i}}$ - value of the $\boldsymbol{i}$-th cylinder liner wear (increase in the inner diameter) $[\mathrm{m}], \mu$

$\boldsymbol{z}_{r x j}-$ value of radial wear at the level $\boldsymbol{x}=\mathrm{I}, \mathrm{II}, \ldots$, VII and direction $\mathrm{j}=1, . ., 4 \mu \mathrm{m}]$,

$\boldsymbol{z}_{r x \boldsymbol{k}}-$ value of radial wear at the level $\boldsymbol{x}$ and direction $\boldsymbol{k}=j$ $+4[\mu \mathrm{m}]$.

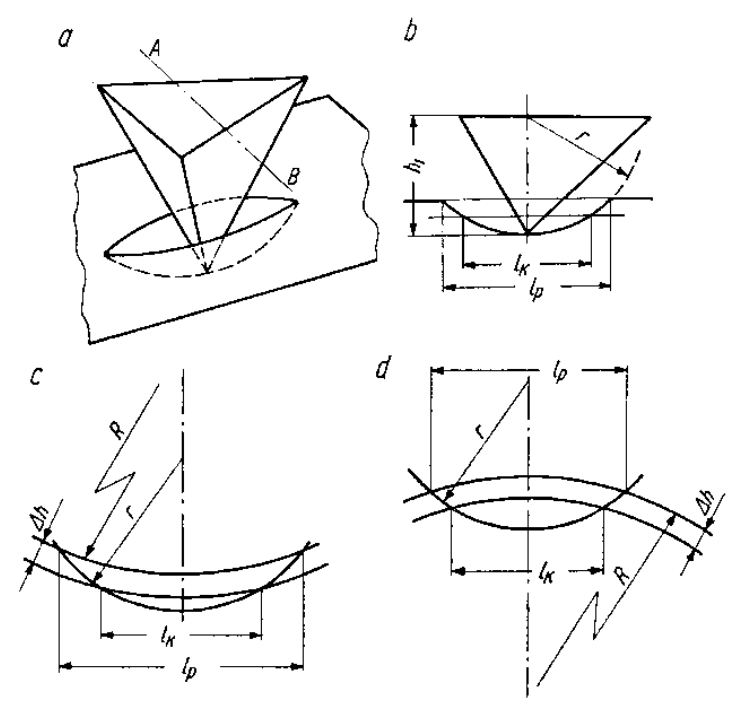

Figure 2. Scheme for calculating the depth of cuts; $\mathbf{R}$ - radius of curvature of the tested surface, $\mathbf{r}-$ knife radius, $\mathbf{l}_{\mathbf{p}}-$ initial cut length, $\mathbf{l}_{\mathbf{k}}-$ final cut length, $\mathbf{h}_{\mathbf{1}}-$ knife height, $\mathbf{\Delta} \mathbf{h}-$ linear wear value

\section{Research results}

After reading the changes in the length of the "artificial base", the wear of the cylinder liner was calculated using the formulas (1) - (2). Then, a preliminary statistical analysis of the obtained results was carried out using the STATISTICA software package, and the elimination of the "gross error" results was performed by calculating the lower limit of the confidence interval:

$$
d_{d}=\bar{d}-t_{1-\alpha_{p i 0} / 2} \cdot \sigma_{d} \cdot \sqrt{\frac{n}{n-2}},
$$

and the upper end of the confidence interval:

$$
d_{g}=\bar{d}+t_{1-\alpha_{p i 0} / 2} \cdot \sigma_{d} \cdot \sqrt{\frac{n}{n-2}},
$$

where:

$\boldsymbol{d}_{\boldsymbol{d}}$-lower end of the confidence interval,

$\boldsymbol{d}_{\boldsymbol{g}}$ - upper end of the confidence interval,

$\boldsymbol{t}_{1 \text {-opi/2 }}$ - quantile of Student's t-distribution with $\mathrm{n}-2$ degrees of freedom.
The results from calculations of the confidence interval limits were obtained at the confidence level $\alpha_{p i / 2}=0.1$ where $\boldsymbol{t}_{1 \text {-opi/2 }}=1.659$ [1]. After taking into account and rejecting the questionable results from further analysis, the final selected parameters of the position and the spread of the start-up wear of the cylinder liners were calculated. Additionally, to compare the obtained values, the results of the cylinder liner wear of the $359 \mathrm{M}$ engine in series 1 and 2 were calculated per 1000 starts. The results of the statistical calculations are presented in Tables 3 and 4.

It should be emphasized that at a temperature of $75^{\circ} \mathrm{C}$ for the series of 4 starts of the 4 C 90 engine, no case of radial wear was found. The measurement method used in the research, based on "artificial bases", turned out to be too "sensitive".

Table 3. Parameters of the position and dispersion of the start-up wear of the cylinder liner after the rejection of questionable results for the 4CT90 engine [4]

\begin{tabular}{|c|c|c|c|}
\hline & Series no. 1 & Series no. 2 & Series no. 3 \\
\hline Average value $d[\mu \mathrm{m}]$ & 3.448 & 1.936 & 1.037 \\
\hline Variance $\operatorname{Var}[\mu \mathrm{m} 2]$ & 2.138 & 2.232 & 1.178 \\
\hline Standard deviation $\mathrm{s}_{\mathrm{d}}[\mu \mathrm{m}]$ & 1.462 & 1.494 & 1.085 \\
\hline Standard error $\mathrm{d}_{\mathrm{d}}[\mu \mathrm{m}]$ & 0.151 & 0.143 & 0.102 \\
\hline Median $m_{e}[\mu \mathrm{m}]$ & 2.357 & 2.149 & 0.0 \\
\hline Mode $[\mu \mathrm{m}]$ & 2.243 & 0.0 & 0.0 \\
\hline Coefficient of variation v $[\%]$ & 42.40 & 77.16 & 104.62 \\
\hline Max.value $[\mu \mathrm{m}]$ & 6,675 & 4.658 & 2.736 \\
\hline Min. value $[\mu \mathrm{m}]$ & 1.808 & 0.0 & 0.0 \\
\hline
\end{tabular}

Table 4. Parameters of the position and dispersion of the start-up wear of the cylinder liner after the rejection of questionable results for the $359 \mathrm{M}$ engine [3]

\begin{tabular}{|c|c|c|c|}
\hline Average value $[\mu \mathrm{m}]$ & Series no. 1 & Series no. 2 & Series no. 3 \\
\hline Variance Var $[\mu \mathrm{m} 2]$ & 7.645 & 6.397 & 6.419 \\
\hline Standard deviation $\mathrm{s}_{\mathrm{d}}[\mu \mathrm{m}]$ & 0.207 & 4.318 & 3.915 \\
\hline Standard error $\mathrm{d}_{\mathrm{d}}[\mu \mathrm{m}]$ & 0.445 & 2.078 & 1.978 \\
\hline Median $m_{e}[\mu \mathrm{m}]$ & 0.051 & 0.222 & 0.214 \\
\hline Mode $[\mu \mathrm{m}]$ & 7.598 & 5.656 & 6.099 \\
\hline Coefficient of variation v $[\%]$ & 7.919 & 5.721 & 6.007 \\
\hline Max.value $[\mu \mathrm{m}]$ & máj.82 & 32.48 & 30.81 \\
\hline Min. value $[\mu \mathrm{m}]$ & 9.406 & 11.116 & sep.44 \\
\hline
\end{tabular}

\subsection{Analysis of the variance of the obtained research results}

In order to determine the influence of temperature and other grouping factors (cylinder, level, direction) on the wear of the engine cylinder liner during its start-up, an analysis of variance was performed using the STATISTICA software package. The first step in this analysis was to investigate 
whether the data came from a normally distributed population and whether all groups of results had the same variance.

The significance level was assumed to be $\alpha=0.05$. The chi-square test $\chi^{2}$ was used for compliance testing with a normal distribution. For testing the homogeneity of variance, the Bartlett B [2] test was adopted (due to the unequal number of results in the analyzed groups).

The results of the analysis for the adopted temperature as the grouping factor for the tested engines are presented in Tables 5 and 6 .

Table 5. Normal and uniformity test results for wear on the 4CT90; grouping factor - engine temperature

\begin{tabular}{|c|c|c|c|c|c|c|}
\hline & \multicolumn{2}{|c|}{$\begin{array}{l}\text { Normality } \\
(\mathrm{N})\end{array}$} & \multicolumn{2}{|c|}{$\begin{array}{l}\text { Homogeneity } \\
\text { (J) }\end{array}$} & \multicolumn{2}{|c|}{ Decision } \\
\hline & $\chi^{2}$ & $\begin{array}{c}\text { value } \\
\mathrm{p}\end{array}$ & B & $\begin{array}{c}\text { value } \\
\mathrm{p}\end{array}$ & $\mathrm{N}$ & $\mathrm{J}$ \\
\hline Series I & 41.13 & 0.000 & \multirow{3}{*}{12.73} & \multirow{3}{*}{0.001} & no & \multirow{3}{*}{ no } \\
\hline Series II & 59.86 & 0.000 & & & no & \\
\hline Series III & 162.0 & 0.000 & & & no & \\
\hline
\end{tabular}

Table 6. Normal and uniformity test results for wear on the $359 \mathrm{M}$ engine; grouping factor - temperature

\begin{tabular}{|c|c|c|c|c|c|c|}
\hline & \multicolumn{2}{|c|}{$\begin{array}{c}\text { Normality } \\
(\mathrm{N})\end{array}$} & \multicolumn{2}{|c|}{$\begin{array}{c}\text { Homogeneity } \\
(\mathrm{J})\end{array}$} & \multicolumn{2}{|c|}{ Decision } \\
\hline & $\chi^{2}$ & $\begin{array}{c}\text { value } \\
\mathrm{p}\end{array}$ & B & $\begin{array}{c}\text { value } \\
\mathrm{p}\end{array}$ & $\mathrm{N}$ & $\mathrm{J}$ \\
\hline Series I & 3.520 & 0.1720 & \multirow{3}{*}{141.0} & \multirow{3}{*}{0.00} & yes & \multirow{3}{*}{ no } \\
\hline Series II & 3.437 & 0.0637 & & & yes & \\
\hline Series III & 8.082 & 0.0886 & & & yes & \\
\hline
\end{tabular}

Based on the results presented in Tables 5 and 6, it is seen that the observed values of the wear of cylinder liner diameters for the $359 \mathrm{M}$ engine can be adjusted with the normal distribution, as opposed to the wear in the 4CT90 engine. This is confirmed by earlier studies $[3,4]$. In the statistical calculations for the analysed engines, it was also found that the normality tests were not met for the following grouping factors: cylinder, level and measuring direction.

Since the assumptions of the classic analysis of variance for the observed wear of the cylinder liner diameters of the 4CT90 and 359M engines during start-up were not fulfilled, a non-parametric method was used in the further analysis of variance using the Kruskal-Wallis K-W [2]. The results of this analysis are presented in Tables 7 and 8 .

When analysing the results of the variance analysis presented in Table 7, it can be concluded that the temperature has a significant impact on the wear observed during the start-up of the 4CT90 engine.
Table 7. Kruskal-Wallis test results for 4CT90 engine wear (various grouping factors)

\begin{tabular}{|c|c|c|c|}
\hline Grouping factor & K-W & p value & $\begin{array}{c}\text { The influence of } \\
\text { the factor on wear }\end{array}$ \\
\hline Temperature & 102.06 & 0.0000 & significant \\
\hline Cylinder & 20.519 & 0.0001 & significant \\
\hline Cylinder in series I & 14.751 & 0.0021 & significant \\
\hline Cylinder in series II & 12.036 & 0.0073 & significant \\
\hline Cylinder in series II & 5.249 & 0.1545 & insignificant \\
\hline Level & 6.120 & 0.4098 & insignificant \\
\hline Level in series I & 14.1418 & 0.0281 & significant \\
\hline Level in series II & 3.017 & 0.8066 & insignificant \\
\hline Level in series III & 7,912 & 0.2446 & insignificant \\
\hline Direction & 1.800 & 0.6148 & Insignificant \\
\hline Direction in series I & 2.6954 & 0.4410 & Insignificant \\
\hline Direction in series II & 2.5255 & 0.4707 & Insignificant \\
\hline Direction in series III & 0.7878 & 0.8524 & Insignificant \\
\hline
\end{tabular}

During the start-up, the influence of another grouping factor, i.e. the cylinder, on the wear values of the cylinder liner is additionally observed. This is probably due to the lower lubrication of the last cylinder liner. Figures 3, 4 and 5 show categorized frame charts the value of cylinder liner wear for two grouping factors (temperature and cylinder for start-ups at $18^{\circ} \mathrm{C}$ and $35^{\circ} \mathrm{C}$ ) of the $4 \mathrm{CT} 90$ engine.

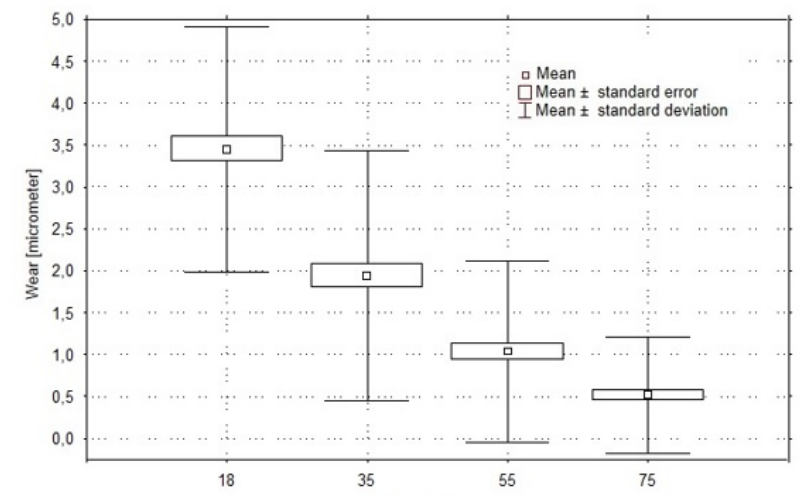

Figure 3. Categorized box plot for the temperature grouping factor and the dependent variable - wear on the cylinder liner diameter of the 4CT90 engine during its start-ups 


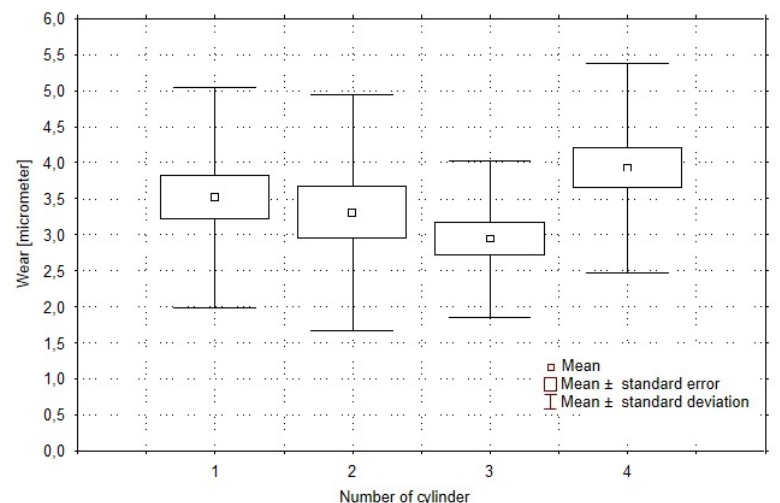

Figure 4. Categorized box plot for the cylinder grouping factor and dependent variable - wear on the cylinder liner diameter of the 4CT90 engine during its start-ups in series I

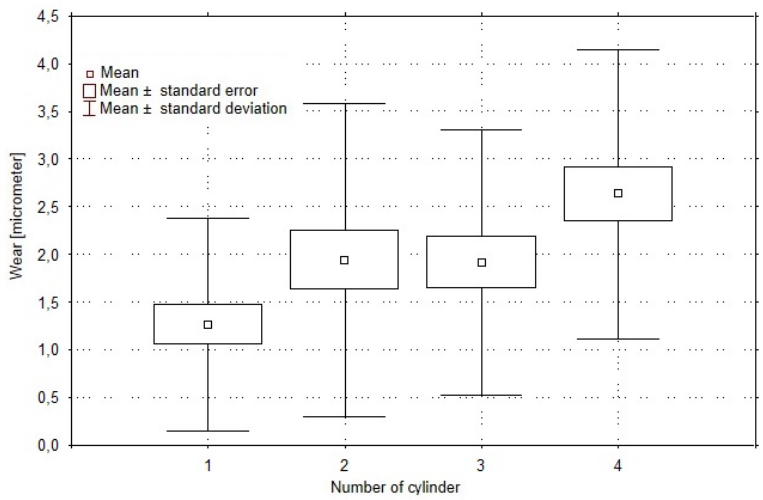

Figure 5. Categorized box plot for the cylinder grouping factor and dependent variable - cylinder liner wear on the cylinder liner diameter of the 4CT90 engine during its start-ups in series II

Table 8. Kruskal-Wallis test results for 359M engine wear (various grouping factors)

\begin{tabular}{|c|c|c|c|}
\hline Grouping factor & K-W & p value & $\begin{array}{c}\text { The influence of } \\
\text { the factor on wear }\end{array}$ \\
\hline Temperature & 22.297 & 0.000 & significant \\
\hline Cylinder & 6.467 & 0.2633 & insignificant \\
\hline Cylinder in series I & 2.683 & 0.7487 & insignificant \\
\hline Cylinder in series II & 14.040 & 0.0154 & significant \\
\hline Cylinder in series III & 5.889 & 0.3376 & insignificant \\
\hline Level & 2.753 & 0.4308 & insignificant \\
\hline Level in series I & 0.775 & 0.8553 & insignificant \\
\hline Level in series II & 1.110 & 0.7746 & insignificant \\
\hline Level in series III & 1.017 & 0.7970 & insignificant \\
\hline Direction & 1.984 & 0.5756 & insignificant \\
\hline Direction in series I & 2.059 & 0.5602 & insignificant \\
\hline Direction in series II & 2.045 & 0.5630 & insignificant \\
\hline Direction in series III & 5.045 & 0.1685 & insignificant \\
\hline
\end{tabular}

When analysing the results of the variance analysis presented in Table 8 , it can be concluded that the temperature has a significant impact on the wear observed during the start-up of the 359M engine. Figure 6 shows the categorized box plot of the cylinder liner wear value for the grouping factor, i.e. the $359 \mathrm{M}$ engine start-up temperature.

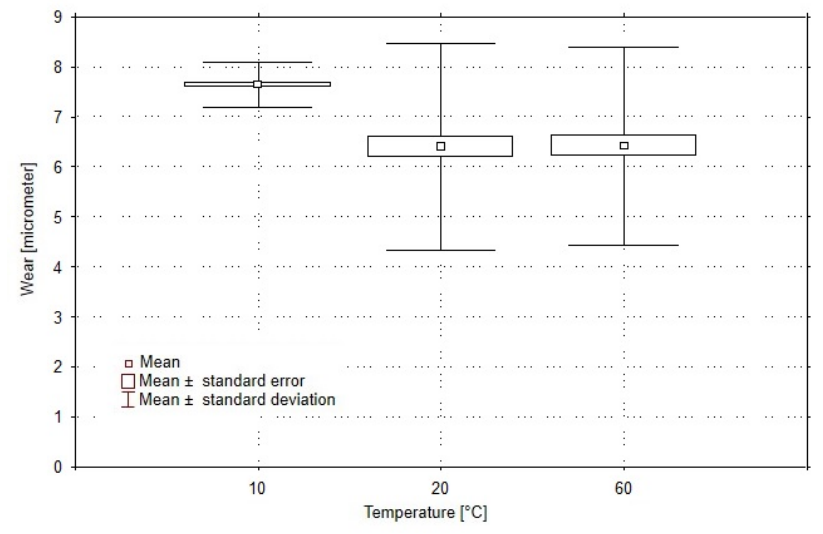

Figure 6. Categorized box plot for the temperature grouping factor and the dependent variable - wear on the cylinder liner diameter of the $359 \mathrm{M}$ engine during its start-ups

\section{Conclusions}

Based on the performed tests and the conducted statistical analysis of the obtained results from the cylinder liner wear assessment in 4CT90 and 359M diesel engines, it can be concluded that:

- The start-up wear of the cylinder liner bearing surface, measured by the increase in its internal diameter, depends significantly on the value of the engine start-up temperature. This is due to the increase in the influence of negative tribological processes on the wear intensity of the finishing coats as the temperature drops.

- The start-up wear value also depends on the type of injection. The use of indirect injection in a split combustion chamber (4CT90 engine) limits the variability of dynamic loads occurring in the PRC system. This improves the lubrication conditions in its tribological pairs and reduces the start-up wear.

- The value of the starting wear of cylinder liners of the tested engines does not depend on the direction and level of assessment. This observation is quite interesting because, according to other researchers, the wear value along the running surface of the cylinder liner during operation depends on the position in relation to the surface of the engine block (the TDC of the top ring).

- The occurrence of a significant field of scattering of the observed values of cylinder liner wear during engine start-up results from the complex friction process in the PRC system, and the accuracy of the "artificial base" method.

\section{REFERENCES}

[1] Bobrowski D.: Probabilistyka w zastosowaniach technicznych. WNT. Warszawa, 1986.

[2] Dobosz M.: Wspomagana komputerowo statystyczna analiza wyników badań. EXIT. Warszawa, 2001. 
[3] Droździel P.: Изнашивание цилиндровых втулок в период пуска двигателя внутренного. Трение и износ. Том 22, № 6. Ноябрь - декабрь, 2001, s. 664-670.

[4] Droździel P., Ignaciuk P.: Zużycie tulei cylindrowych podczas rozruchu spalinowego silnika 4C90 o zapłonie samoczynnym. Zagadnienia Eksploatacji Maszyn, z. 4 (136), vol. 38. Polska Akademia Nauk, Komitet Budowy Maszyn, Radom, 2003.

[5] Holmes K.: Solid Materials. Engine Tribology. Tribology Series 26. Elsevier, 1993.

[6] Koliński K, Pszczółkowski J.: Zużycie cylindrów silnika AD4.236 w warunkach rozruchu. Eksploatacja silników spalinowych. Zeszyt nr 6. Problemy rozruchu silników spalinowych. Komisja Motoryzacji i Energetyki Rolnictwa PAN O/Lublin, Politechnika Szczecińska. Szczecin, 2002.
[7] Lawrowski Z.: Tribologia - Tarcie, zużywanie i smarowanie. PWN. Warszawa, 1993.

[8] Lewicki J.: Opory tarcia i zużycie silników z zapłonem samoczynnym przy rozruchu w niskich temperaturach. Prace Naukowe Politechniki Szczecińskiej. Nr 353. Szczecin, 1988.

[9] Smith M. F.: Understanding diesel engine lubrication at low temperature. SAE Paper 902177, 1990.

[10] Taylor C. M.: Lubrication regimes and the internal combustion engine. Engine Tribology. Tribology Series 26. Elsevier, 1993. [5]

[11] Włodarski J. K.: Tłokowe silniki spalinowe - procesy tribologiczne. WKiŁ. Warszawa, 1982. 